University of Nebraska - Lincoln

DigitalCommons@University of Nebraska - Lincoln

\title{
Thermal death kinetics and heatingrate effects for fifth-instar Cydia pomonella (L.) (Lepidoptera: Tortricidae)
}

\author{
S. Wang \\ Washington State University \\ J. N. Ikediala \\ Washington State University \\ J. Tang \\ Washington State University \\ J. D. Hansen \\ USDA-ARS
}

Follow this and additional works at: https://digitalcommons.unl.edu/usdaarsfacpub

Part of the Agricultural Science Commons

Wang, S.; Ikediala, J. N.; Tang, J.; and Hansen, J. D., "Thermal death kinetics and heatingrate effects for fifth-instar Cydia pomonella (L.) (Lepidoptera: Tortricidae)" (2002). Publications from USDA-ARS / UNL Faculty. 351.

https://digitalcommons.unl.edu/usdaarsfacpub/351

This Article is brought to you for free and open access by the U.S. Department of Agriculture: Agricultural Research Service, Lincoln, Nebraska at DigitalCommons@University of Nebraska - Lincoln. It has been accepted for inclusion in Publications from USDA-ARS / UNL Faculty by an authorized administrator of DigitalCommons@University of Nebraska - Lincoln. 


\title{
Thermal death kinetics and heating rate effects for fifth-instar Cydia pomonella (L.) (Lepidoptera: Tortricidae)
}

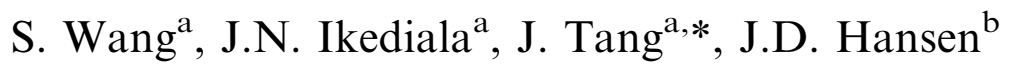 \\ ${ }^{a}$ Department of Biological Systems Engineering, Washington State University, 213 L.J. Smith Hall, \\ Pullman, WA 99164-6120, USA \\ ${ }^{\mathrm{b}}$ USDA-ARS Yakima Agricultural Research Laboratory, 5230 Konnowac Pass Road, Wapato, WA 98951, USA
}

Accepted 4 September 2001

\begin{abstract}
Thermal death kinetic parameters of fifth-instar codling moths (Cydia pomonella (L.)) and the effect of three heating rates $\left(1^{\circ} \mathrm{C} \mathrm{min}^{-1}, 10^{\circ} \mathrm{C} \mathrm{min}^{-1}\right.$, and $\left.18^{\circ} \mathrm{C} \mathrm{min}^{-1}\right)$ on larval mortality were determined by a heating block system. The insects were heated to four temperatures $\left(46^{\circ} \mathrm{C}, 48^{\circ} \mathrm{C}, 50^{\circ} \mathrm{C}\right.$, and $\left.52^{\circ} \mathrm{C}\right)$ held for predetermined periods followed by $24 \mathrm{~h}$ storage at $4^{\circ} \mathrm{C}$ before mortality evaluation. Thermal death kinetics for fifth-instar codling moths followed a 0.5 th order of kinetic reaction. Minimum time required to achieve $100 \%$ mortality of a given population decreased with temperature in a semi-logarithmic manner. No larval survival was observed in samples of 600 insects after exposure to $46^{\circ} \mathrm{C}, 48^{\circ} \mathrm{C}, 50^{\circ} \mathrm{C}$, and $52^{\circ} \mathrm{C}$ for $50,15,5$, and $2 \mathrm{~min}$, respectively. Activation energy for thermal kill of fifth-instar codling moths at the heating rate of $18^{\circ} \mathrm{C} \mathrm{min}^{-1}$ was estimated to be about $472 \mathrm{~kJ} \mathrm{~mol}^{-1}$. The lethal time accumulated during the ramp period was about $1.8,0.2$, and $0.1 \mathrm{~min}$ for the heating rates of $1{ }^{\circ} \mathrm{Cmin}^{-1}, 10^{\circ} \mathrm{Cmin}^{-1}$, and $18^{\circ} \mathrm{C} \mathrm{min}{ }^{-1}$, respectively. (C) 2002 Elsevier Science Ltd. All rights reserved.
\end{abstract}

Keywords: Thermal death time; Kinetics; Heating block; Heating rate; Codling moth; Quarantine treatment

\section{Introduction}

Interest in using heat treatments to provide quarantine security against pests in fresh and stored agricultural commodities has increased in the wake of regulatory actions over the use of pesticides. Concerns about pesticide effects on humans and the environment and implementation of the US Food Protection Act of 1996 will further limit use and availability of some widely used chemical fumigants, especially methyl bromide, against codling moth in fruits and nuts

\footnotetext{
*Corresponding author. Tel.: + 1-509-335-2140; fax: + 1-509-335-2722.

E-mail address: jtang@mail.wsu.edu (J. Tang).
} 
(UNEP, 1995). An understanding of intrinsic mortality parameters and relationships between applied heat and its cumulative effect on both pest and commodity is necessary for determining the suitability and effectiveness of an alternative heat treatment method.

Infesting pests differ very widely in tolerance to heat treatments. Thus, knowledge of the minimum required thermal energy to control infesting insects over a relatively large range of temperatures would provide flexibility for the design of suitable and effective thermal quarantine processes. Several researchers have reported heat resistance of codling moth instars (Yokoyama et al., 1991; Neven, 1994; Neven and Rehfield, 1995; Neven and Mitcham, 1996; Ikediala et al., 1999). Jang (1991) observed that much of the research on the application of heat treatments to obtain quarantine security has not been systematic. For example, different experimental and heat application methods have been used to assess the thermal resistance of codling moths, and reported information for codling moth or other insects is often confounded by the heat transfer phenomenon and the heat application method employed.

Heating rate is believed to have a significant effect on insect metabolism and physiological adjustment to the heat treatment (Evans, 1986; Neven, 1998a, b). Neven (1998a) reported that codling moth larvae might experience thermal conditioning and acclimation to the heat at heating rates between $0.13^{\circ} \mathrm{Cmin}^{-1}$ and $0.2^{\circ} \mathrm{C} \mathrm{min}^{-1}$. Consequently, a longer holding time is required at a final temperature in order to achieve the same mortality after a slower heating rate. For conventional heating, the heating rates in the interior of commodities ranged between $0.05^{\circ} \mathrm{C} \mathrm{min}^{-1}$ and $2^{\circ} \mathrm{C} \mathrm{min}{ }^{-1}$, depending on heating methods, type and size of commodity, and the end temperature (Wang et al., 2001b). In addition, the heating rate at the interior of a commodity decreases with time under a constant treatment condition due to decreasing temperature difference between the heating medium and the fruit. As a result, conventional heat treatments typically take long times to achieve required security against insects. Most insects may have adequate time to adapt to the heat and increase thermal resistance (Waddell et al., 2000).

Fast heating methods $\left(10-20^{\circ} \mathrm{C} \mathrm{min}^{-1}\right.$ heat rates) based on radio frequency (RF) and microwave energy have been proposed to control insect pests in commodities to replace chemical fumigation (Nelson and Payne, 1982; Ikediala et al., 1999, 2001; Tang et al., 2000; Wang et al., 2001a). Recently, Ikediala et al. (2002) and Wang et al. (2001a) reported thermal treatment methods using $27 \mathrm{MHz}$ RF energy to control codling moths in cherries and walnuts without significantly reducing product quality. Therefore, there is a need to study the effect of all possible heating rates on the thermal death kinetics of insects.

The objectives in this research were to study the thermal death time (TDT) kinetics of fifthinstar codling moths and to determine the effect of heating rates on mortality of this insect pest.

\section{Materials and methods}

\subsection{Heating block system}

A computer-controlled heating block system which provided heating rates from $0.1^{\circ} \mathrm{C} \mathrm{min}^{-1}$ to $20^{\circ} \mathrm{C} \mathrm{min}^{-1}$ was developed at Washington State University, Pullman, WA for studying thermal death kinetics of insect pests. Details of this heating system have been described in Ikediala et al. (2000) and the improved version in Wang et al. (2002). The death rate kinetics and the effect of heating rates on thermal mortality of insects were investigated using this heating system. 


\subsection{Heat treatment of codling moth larvae and mortality analyses}

Fifth-instar codling moths, Cydia pomonella (L.), were used in experimental heat treatments. Yokoyama et al. (1991) showed this developmental stage to be the most heat tolerant. Codling moth larvae were obtained from the USDA-ARS Yakima Agricultural Research Laboratory, Wapato, WA. Before each heat treatment, 200 larvae were extracted from artificial diet (Toba and Howell, 1991) and placed in the heating block chamber. The system temperature was then ramped up at one of three heating rates $\left(1^{\circ} \mathrm{C} \mathrm{min}{ }^{-1}, 10^{\circ} \mathrm{C} \mathrm{min}^{-1}\right.$, and $\left.18^{\circ} \mathrm{C} \mathrm{min}^{-1}\right)$ to $46^{\circ} \mathrm{C}, 48^{\circ} \mathrm{C}, 50^{\circ} \mathrm{C}$ and $52^{\circ} \mathrm{C}$. Insects were held at those final temperatures for three to five different periods that varied between $0.5 \mathrm{~min}$ at $52^{\circ} \mathrm{C}$ and $10 \mathrm{~min}$ at $46^{\circ} \mathrm{C}$. These holding periods would allow a wide range of mortality levels including $100 \%$. The heating rate of $1^{\circ} \mathrm{C} \mathrm{min}^{-1}$ was selected to simulate the slow heating for fruits using conventional heat treatments such as forced hot air and hot water baths and the heating rates of $10^{\circ} \mathrm{C} \mathrm{min}^{-1}$ and $18^{\circ} \mathrm{C} \mathrm{min}^{-1}$ were used to simulate the fast heating for fruits using RF and microwave energies.

To compare the effect of heating rates on insect mortality, four temperature-time combinations, $46^{\circ} \mathrm{C}+40 \mathrm{~min}, 48^{\circ} \mathrm{C}+5 \mathrm{~min}, 50^{\circ} \mathrm{C}+2 \mathrm{~min}$, and $52^{\circ} \mathrm{C}+1 \mathrm{~min}$, were selected just below a complete kill level as described by the TDT curve (defining minimum temperature-time required to achieve $100 \%$ mortality in a given sample) developed at the heating rate of $18^{\circ} \mathrm{Cmin}^{-1}$.

Control larvae were placed in the unheated block chamber for $50 \mathrm{~min}$. For each temperature and holding time combination, including controls, 200 larvae were treated at a time and all treatments were repeated three times for a total of 600 larvae.

Commercial treatments would include rapid post-treatment cooling of cherries to minimize the effect on product quality, so the treated larvae were immediately moved to cold storage at $4^{\circ} \mathrm{C}$ and stored at this temperature for 1 day. After the cold storage, the larvae were held at $23^{\circ} \mathrm{C}, 60 \% \mathrm{RH}$ in a 16:8 (L:D)h photoperiod for 1 day to minimize the effect of cold stupor before examination. Procedures for observing treated insects and calculating insect mortality were similar to those described in Wang et al. (2002).

\subsection{Insect thermal kinetic modeling}

Different methods have been used to analyze thermal resistance of insects. Probit analysis is the most common method. It is based on the assumption that the frequency of individual deaths in an insect population under constant temperature follows the standard normal distribution with cumulative probability of death increasing with time (Finney, 1971; Sokhansanj et al., 1990; Tang and Sokhansanj, 1993). The probit analysis neither gives the kinetic parameters for insect thermal mortality nor provides sufficient information from which new or other temperature-time combinations can be chosen. Thomas and Mangan (1997) critically reviewed several models for Mexican fruit flies. They recommended the use of a thermal dynamic kinetic model for estimating the efficacy of quarantine treatments in developing new treatment methods, but recommended use of the traditional probit analysis for confirming estimates. Jang $(1986,1991)$ detailed the advantages of the kinetic model for determining the thermal death rate parameters of fruit flies. Earlier, the use of probit 9 mortality as a criterion to ensure quarantine treatment security of fruits infested by fruit flies and other pests had been questioned by Landolt et al. (1984). 
Several researchers have suggested that the logarithmic order of death was not always followed by microorganisms (Alderton and Snell, 1970; Moats, 1971; King et al., 1979). Jang (1986, 1991) used a modified logarithmic formula derived by Alderton and Snell (1970) to model thermal mortality of fruit flies. Thus, the knowledge of the fundamental kinetics for thermal death of insects allows the prediction of lethal times (LT) over a range of temperatures. Tang et al. (2000) described the TDT concept in detail and its applicability to model insect pest heat destruction kinetics. A significant advantage of the thermal kinetic model, whenever suitable to model death rates over the probit method, is the ability to predict the efficacy of a thermal process based on temperature-time history in host materials.

In developing a kinetic model to describe thermal kill of codling moth larvae, we used a classical kinetic model approach in which we determined the order of reaction and then determined the activation energy based on the dependence of reaction rate on temperature. In this analysis, the ratio change of insect survivals $(N)$ to initial insect number $\left(N_{0}\right)$ during thermal treatments was modeled as following the fundamental kinetic model:

$$
\frac{d\left(N / N_{0}\right)}{\mathrm{d} t}=-k\left(N / N_{0}\right)^{n}
$$

where $n$ is the kinetic order of reactions. The integration form of Eq. (1) was obtained for different reaction orders as follows:

$$
\begin{array}{ll}
\ln \left(N / N_{0}\right)=-k t+c & (n=1), \\
\left(N / N_{0}\right)^{1-n}=-k t+c & (n \neq 1) .
\end{array}
$$

A linear regression analysis was performed in this study for the $0-, 0.5$ th-, 1 st, 1.5 th- and 2nd-order of reactions. The best-fitted line was determined by comparing the coefficients of determination $\left(R^{2}\right)$ for all the treated temperatures. After the reaction order was determined and the corresponding best-fit values of the constants $k$ and $c$ were obtained, the model was used to estimate the lethal time $\mathrm{LT}_{95}, \mathrm{LT}_{99}, \mathrm{LT}_{99.83}$, and $\mathrm{LT}_{99.9968}$.

The activation energy for thermal inactivation of test larvae was estimated from the relationship between $k$ and $T$ on an Arrhenius plot (Stumbo, 1973; Tang et al., 2000):

$$
k=k_{r e f} \mathrm{e}^{\left(-E_{A} / R\right)\left((1 / T)-\left(1 / T_{r e f}\right)\right)},
$$

where $T$ is the absolute temperature $\left({ }^{\circ} \mathrm{K}\right), k_{\text {ref }}$ is the reaction rate constant at the reference temperature $T_{r e f}\left({ }^{\circ} \mathrm{K}\right), E_{A}$ is the activation energy $\left(\mathrm{J} \mathrm{mol}^{-1}\right)$, and $R$ is the universal gas constant $\left(8.314 \mathrm{~J} \mathrm{~mol}^{-1}{ }^{\circ} \mathrm{K}^{-1}\right)$.

The activation energy $E_{A}$ for thermal kill of codling moths was also estimated from a TDT curve (Tang et al., 2000):

$$
E_{A}=\frac{2.303 R T_{\min } T_{\max }}{z}
$$

where $T_{\min }$ and $T_{\max }$ are the minimum and maximum temperatures $\left({ }^{\circ} \mathrm{K}\right)$ of a test range, respectively. $z$ is the degrees of temperature increase required to result in one log reduction in time on a TDT curve. The $z$ value in the theory of Thermobacteriology is related to the value of rate constant and activation energy in the classical reaction kinetic theory.

Once the $z$ value, or $k$ and $E_{A}$ values, for a target insect pest are determined, the accumulated temperature-time effect of a thermal treatment with a known temperature history on reduction of 
the organism can then be predicted with good accuracy (Tang et al., 2000). This method has been the basis for calculating the thermal processing times for commercial food thermal pasteurization and sterilization processes (Stumbo, 1973).

\subsection{Cumulative effect of ramp period}

Different heating rates resulted in different ramp periods to reach the same holding temperature. It is possible to estimate the cumulative effect (corrected holding time) due to the temperature ramp periods. For first order kinetics, we may use the following relationship to approximately determine the cumulative effect for any given temperature-time history (Tang et al., 2000), in terms of equivalent total LT $M_{\text {accum }}(\mathrm{min})$ at a reference temperature, $T_{\text {ref }}\left({ }^{\circ} \mathrm{C}\right)$ :

$$
M_{\text {accum }}=\int_{0}^{t} 10^{\left(T(t)-T_{\text {ref }}\right) / z} \mathrm{~d} t .
$$

The temperature-time history $T(t)$ for the treatments used in this study is presented in Fig. 1, where $T_{0}$ is the starting temperature $\left({ }^{\circ} \mathrm{C}\right) ; T_{h}$ is the holding temperature $\left({ }^{\circ} \mathrm{C}\right) ; t_{0}$ and $t_{1}$ are the times (min) at the end of the ramp and the holding period, respectively. During the ramp period, the temperature is a linear function of time, and can be expressed as $T(t)=T_{0}+\alpha t$, where $\alpha$ is the heating rate $\left({ }^{\circ} \mathrm{C} \mathrm{min}{ }^{-1}\right)$. With this relationship and using the holding temperature as the reference temperature $\left(T_{r e f}=T_{h}\right)$, Eq. (5) can be directly integrated between the limits $t=0$ and $t=t_{1}$ into:

$$
M_{\text {accum }}=\frac{z}{2.303 \alpha}\left[1-10^{-\left(T_{0}-T_{h}\right) / z}\right]+\left(t_{1}-t_{0}\right),
$$

where the first term represents the equivalent LT at the holding temperature accumulated during the ramp period, and the second term corresponds to the actual holding time. The above relation can be used to compare treatments at different heating rates, holding times and temperatures (Tang et al., 2000). An average $z$ value of $4{ }^{\circ} \mathrm{C}$ was used, based on the results of Ikediala et al.

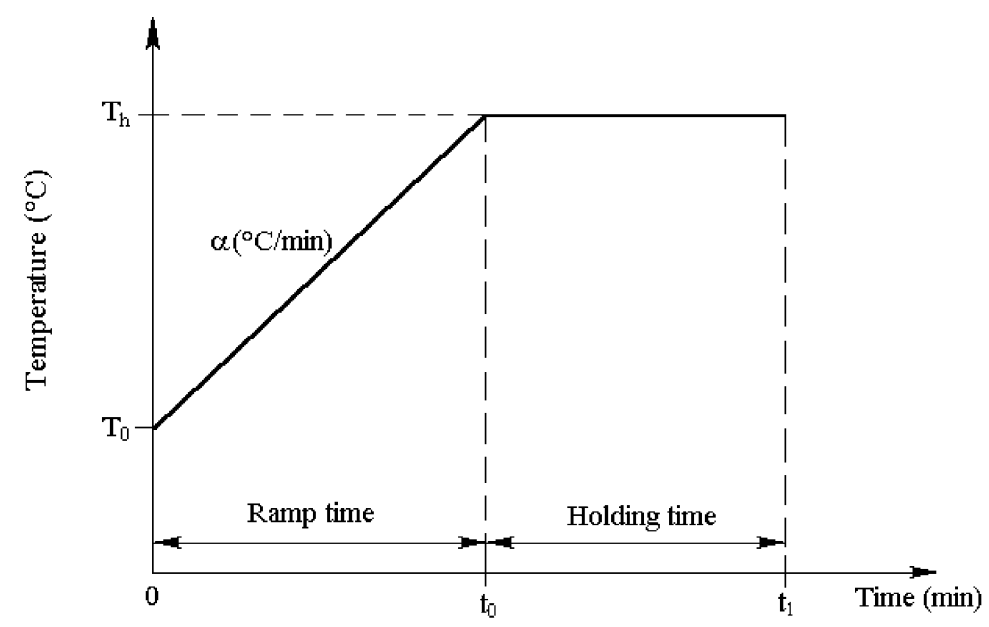

Fig. 1. Typical temperature-time history used in this study. 
(2000), and the initial temperature was $22^{\circ} \mathrm{C}$. The corrected treatment times corresponding to the three heating rates for the holding temperatures of $46^{\circ} \mathrm{C}, 48^{\circ} \mathrm{C}, 50^{\circ} \mathrm{C}$, and $52^{\circ} \mathrm{C}$ were compared.

\section{Results and discussion}

\subsection{Kinetics of codling moth mortality}

The survival in unheated controls was high $(92.4 \pm 2.8 \%)$, suggesting negligible effect of shipping and handling. Table 1 gives the coefficients of determination $\left(R^{2}\right)$ for different reaction orders for all the treatment temperatures to kill the codling moth larvae. The first order reaction was best suited to describe thermal mortality kinetics for fifth-instar codling moths at treatment temperatures above $48^{\circ} \mathrm{C}$. But for the overall tested temperature range between $46^{\circ} \mathrm{C}$ and $52^{\circ} \mathrm{C}$, the 0.5 th order reaction was most applicable. The 0.5 th order reaction was also found most suitable for fifth-instar navel orangeworms (Wang et al., 2002).

The thermal mortality curves for fifth-instar codling moths are shown in Fig. 2 together with the best-fit curves based on the 0.5 th order reaction. The thermal death constants for the 0.5 thorder reaction model are presented in Table 2. The established thermal death kinetic model was further used to predict the LT to reach $95 \%, 99 \%, 99.83 \%$, and $99.9968 \%$ mortality (Table 3 ). Table 3 also lists the observed minimum holding times at each temperature to achieve $100 \%$ mortality in tested samples. Complete kill in samples of 600 insects was obtained after holding at $46,48,50$, and $52^{\circ} \mathrm{C}$ for $50,15,5$, and $2 \mathrm{~min}$, respectively. The predicted values for $\mathrm{LT}_{99.83}$ and $\mathrm{LT}_{99.9968}$ were close to the observed results with samples of 600 insects. The discrepancy might have been caused by the limited resolution due to experimental holding time intervals (e.g., 0.5 to $1 \mathrm{~min}$ at $52^{\circ} \mathrm{C}$ but 10 to $15 \mathrm{~min}$ at $46^{\circ} \mathrm{C}$ ) used in experiments at each holding temperature (Fig. 2). As expected, percentage mortality increased with increasing temperature and holding time. It is interesting to note in Table 3 that only about $10 \%$ extra time was needed to increase the efficacy of a heat treatment from $99 \%$ mortality to $99.9968 \%$ (Probit 9) when fifth-instar codling moths were fully exposed to a constant temperature.

Fig. 3 shows a TDT curve at the heating rate of $18^{\circ} \mathrm{Cmin}^{-1}$ that defines the minimum temperature and time requirements with the selected time intervals to achieve $100 \%$ kill of samples of 600 insects. The $z$ value was estimated to be $4.2^{\circ} \mathrm{C}$ from the TDT curve. The observed

Table 1

Estimation of the best kinetic order $(n)$ for the thermal kill of fifth-instar codling moths at four temperatures by comparing the coefficients of determination $\left(R^{2}\right)$

\begin{tabular}{llllll}
\hline Temperatures $\left({ }^{\circ} \mathrm{C}\right)$ & \multicolumn{4}{l}{$R^{2}$ for different order $n$} \\
\cline { 2 - 6 } & $n=0$ & $n=0.5$ & $n=1$ & $n=1.5$ & $n=2$ \\
\hline 46 & 0.991 & 0.954 & 0.663 & 0.479 & 0.460 \\
48 & 0.868 & 0.965 & 0.885 & 0.492 & 0.412 \\
50 & 0.735 & 0.857 & 0.972 & 0.876 & 0.858 \\
52 & 0.819 & 0.957 & 0.940 & 0.789 & 0.769 \\
\hline
\end{tabular}




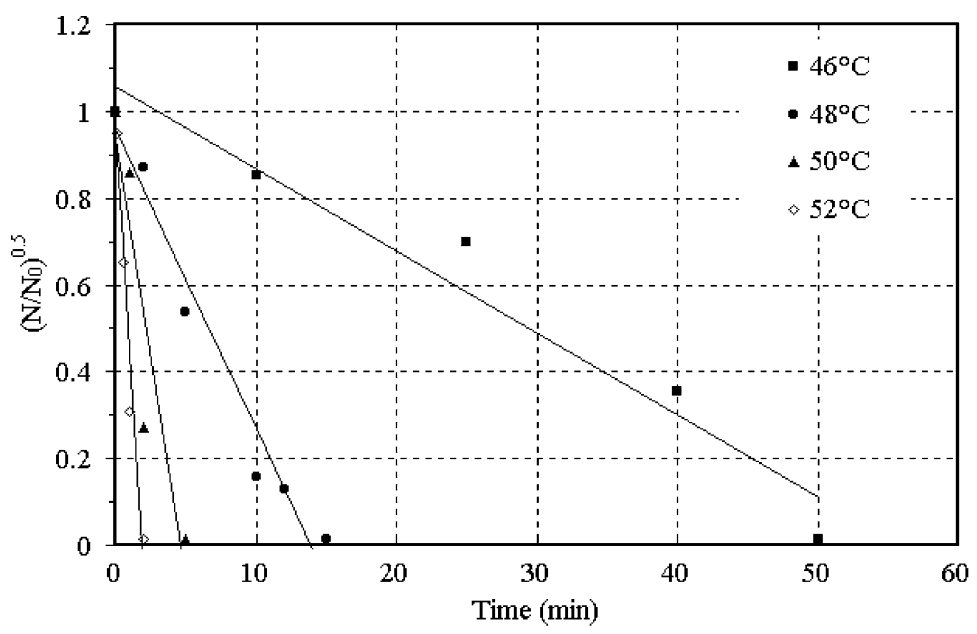

Fig. 2. Thermal mortality curve of fifth-instar codling moths at different temperatures and at the heating rate of $18^{\circ} \mathrm{C} \mathrm{min}^{-1}$. Each point represents 600 larvae and the lines were obtained by regression using a 0.5 th order reaction model. $N_{0}$ and $N$ stand for initial and survival insect numbers.

Table 2

Thermal death constants for 0.5 th order reaction model for fifthinstar codling moth at four temperatures and the heating rate of $18^{\circ} \mathrm{Cmin}^{-1}$

\begin{tabular}{lll}
\hline $\begin{array}{l}\text { Temperature } \\
\left({ }^{\circ} \mathrm{C}\right)\end{array}$ & \multicolumn{2}{l}{ Thermal death constants of $\left(N / N_{0}\right)^{0.5}=-k t+c$} \\
\cline { 2 - 3 } & $k \pm \mathrm{SE}$ & $c \pm \mathrm{SE}$ \\
\hline 46 & $0.0189 \pm 0.0024$ & $1.0555 \pm 0.0984$ \\
48 & $0.0691 \pm 0.0066$ & $0.9584 \pm 0.0869$ \\
50 & $0.2016 \pm 0.0581$ & $0.9401 \pm 0.2175$ \\
52 & $0.5056 \pm 0.0620$ & $0.9488 \pm 0.1013$ \\
\hline
\end{tabular}

Table 3

Comparison of lethal times (LT, min) obtained by experiments and 0.5 th order kinetic models (Eq. (2)) for fifth-instar codling moths at four temperatures and the heating rate of $18^{\circ} \mathrm{C} \mathrm{min}^{-1}$, followed by $24 \mathrm{~h}$ cold storage at $4^{\circ} \mathrm{C}$

\begin{tabular}{llllll}
\hline Temperature & $\begin{array}{l}\text { Observed } \\
\left({ }^{\circ} \mathrm{C}\right)\end{array}$ & $\begin{array}{l}\text { 100\% mortality for } \\
600 \text { insects (min) } \\
\left(\sim \mathrm{LT}_{99.83}\right)\end{array}$ & \multicolumn{4}{l}{0.5 th order kinetic model } \\
\cline { 3 - 6 } & & $\mathrm{LT}_{95}$ & $\mathrm{LT}_{99}$ & $\mathrm{LT}_{99.83}$ & $\begin{array}{l}\mathrm{LT}_{99.9968} \\
\text { (probit 9) }\end{array}$ \\
\hline 46 & 50 & 44.0 & 50.6 & 53.7 & 55.6 \\
48 & 15 & 10.6 & 12.4 & 13.3 & 13.8 \\
50 & 5 & 3.6 & 4.2 & 4.5 & 4.6 \\
52 & 2 & 1.4 & 1.7 & 1.8 & 1.9 \\
\hline
\end{tabular}




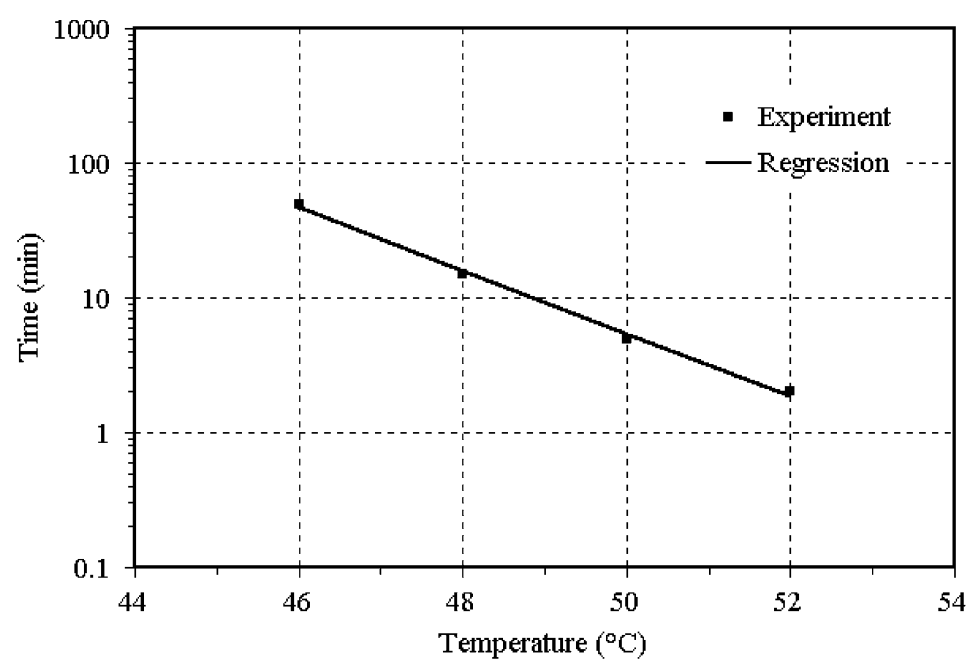

Fig. 3. Thermal-death-time curve defines minimum temperature-time to completely kill 600 fifth-instar codling moths at a heating rate of $18^{\circ} \mathrm{C} \mathrm{min}^{-1}$. The straight line $(\log t=12.41-0.23 T)$ was obtained by linear regression $\left(R^{2}=0.996\right)$.

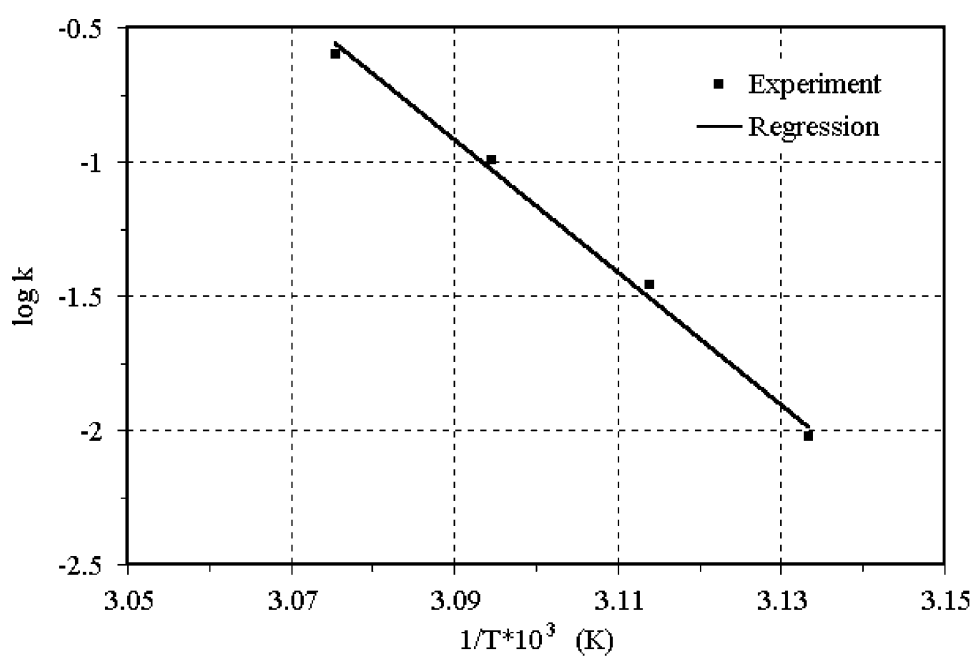

Fig. 4. Arrhenius plot for temperature effects on thermal death rates of fifth-instar codling moths. The straight line $(\log k=75.22-24.64 \times 1000 / T)$ was obtained by linear regression $\left(R^{2}=0.995\right)$.

exposure time for $100 \%$ mortality of all 600 test insects corresponded to the estimated LT needed to achieve at least $99.83 \%$ mortality at a given temperature. The relationship $(\log t=12.41-$ $0.23 T$ ) between the observed exposure times to achieve $100 \%$ insect mortality and the treated temperatures was obtained by linear regression with $R^{2}=0.996$. The value of $k$ obtained from 0.5 th order reaction relationship followed an Arrhenius relationship (Eq. (3)) which is expressed as $\log k=75.22-24.64 \times 1000 / T$ with $R^{2}=0.995$ (Fig. 4). 


\subsection{Activation energy}

The activation energy for thermal kill of fifth-instar codling moth was calculated from Eqs. (3) and (4), based on a $z$ value of $4.2^{\circ} \mathrm{C}$, to be 472 and $473 \mathrm{~kJ} \mathrm{~mol}^{-1}$, respectively. Table 4 compares the activation energy $\left(E_{A}\right)$ of different insect pests, microorganisms, and quality parameters of food commodities. The activation energy for thermal kill of the insects ranged from 400 to $958 \mathrm{~kJ} \mathrm{~mol}^{-1}$. The $E_{A}$ values for fifth-instar codling moths obtained in this study compared well with those of fifth-instar navel orangeworm (Wang et al., 2002) and of the four species of fruit flies reported by Jang (1986, 1991) and Moss and Chan (1993). In general, the activation energy for thermal kill of insects was slightly greater than that for thermal inactivation of pathogenic microbial spores and much greater than for softening and many other quality changes in commodities due to heat (Table 4). Like other insects, codling moth larvae were much more sensitive to increase in treatment temperatures than most fruit quality aspects. This provides an opportunity for the possible development of relatively high-temperature/short-time thermal treatment processes that may kill insects while having minimal impact on product quality (Tang et al., 2000).

\subsection{Effect of heating rates on insect mortality}

Table 5 highlights the effect of three heating rates on insect mortality under four temperatureholding time combinations $\left(46^{\circ} \mathrm{C}+40 \mathrm{~min}, 48^{\circ} \mathrm{C}+5 \mathrm{~min}, 50^{\circ} \mathrm{C}+2 \mathrm{~min}\right.$, and $\left.52^{\circ} \mathrm{C}+1 \mathrm{~min}\right)$. Using

Table 4

Comparisons of activation energies for thermal kill of insects and microorganisms with that for food quality changes due to heat treatments

\begin{tabular}{|c|c|c|c|}
\hline Insects/materials & $\begin{array}{l}\text { Temperature } \\
\text { range }\left({ }^{\circ} \mathrm{C}\right)\end{array}$ & $\begin{array}{l}\text { Activation energy } \\
E_{A}\left(\mathrm{~kJ} \mathrm{~mol}^{-1}\right)\end{array}$ & Source \\
\hline \multicolumn{4}{|l|}{ Mediterranean fruit fly } \\
\hline Eggs & $45-47$ & 784 & Jang (1986) \\
\hline First instar & $45-48$ & 656 & Jang (1986) \\
\hline \multicolumn{4}{|l|}{ Melon fly } \\
\hline Eggs & $43-46$ & 518 & Jang (1986) \\
\hline First instar & $45-48$ & 650 & Jang (1986) \\
\hline \multicolumn{4}{|l|}{ Oriental fruit fly } \\
\hline Eggs & $43-46$ & 958 & Jang (1986) \\
\hline First, early and late third instar & $43-48$ & $209-401$ & Jang $(1986,1991)$ \\
\hline \multirow[t]{2}{*}{ Caribbean fruit fly (eggs) } & $37-42$ & 440 & Moss and Chan (1993) \\
\hline & $43-50$ & 445 & Moss and Chan (1993) \\
\hline Queensland fruit fly (eggs) & $42-48$ & $538^{\mathrm{a}}$ & Waddell et al. (2000) \\
\hline Navel orangeworm (fifth-instar) ${ }^{b}$ & $46-54$ & $510-520$ & Wang et al. (2002) \\
\hline \multirow{2}{*}{ Codling moth (fifth-instar) ${ }^{\mathrm{b}}$} & $46-52$ & 473 & This study (from TDT) \\
\hline & $46-52$ & 472 & This study (from $k-T$ ) \\
\hline $\begin{array}{l}\text { Quality (texture-softening or firmness, } \\
\text { color, flavor, etc.) }\end{array}$ & $50-70$ & $42-126$ & $\begin{array}{l}\text { Lund (1977), Rao and } \\
\text { Lund (1986) }\end{array}$ \\
\hline Microorganisms (spores) & $100-130$ & $222-502$ & Lund (1977) \\
\hline
\end{tabular}

${ }^{\text {a }}$ Estimated by the authors from the reported data.

${ }^{\mathrm{b}}$ Parameter obtained at $18^{\circ} \mathrm{C} \mathrm{min}^{-1}$ heating rate. 
Table 5

Mortality (\%) of fifth-instar codling moths after heat treatments with three different heating rates from $22^{\circ} \mathrm{C}$ and holding for selected periods (three replicates), followed by $24 \mathrm{~h}$ cold storage at $4^{\circ} \mathrm{C}$

\begin{tabular}{llll}
\hline $\begin{array}{l}\text { Temperature }+ \\
\text { holding time }\left({ }^{\circ} \mathrm{C}+\mathrm{min}\right)\end{array}$ & \multicolumn{3}{l}{ Mortality $(\%)$ at heating rates } \\
\cline { 2 - 4 } & $1{ }^{\circ} \mathrm{C} \mathrm{min}^{-1}$ & $10^{\circ} \mathrm{C} \mathrm{min}^{-1}$ & $18^{\circ} \mathrm{C} \mathrm{min}^{-1}$ \\
\hline $46+40$ & $100(24)^{\mathrm{a}}$ & $100(2.4)$ & $87.4 \pm 8.6(1.3)$ \\
$48+5$ & $100(26)$ & $91.3 \pm 6.2(2.6)$ & $71.0 \pm 9.2(1.4)$ \\
$50+2$ & $100(28)$ & $97.3 \pm 1.9(2.8)$ & $92.5 \pm 0.2(1.6)$ \\
$52+1$ & $100(30)$ & $100(3.0)$ & $90.5 \pm 6.4(1.7)$ \\
\hline
\end{tabular}

${ }^{a}$ Value in the parenthesis indicates the ramp time to reach the targeted temperature in min.

the heating rate of $1{ }^{\circ} \mathrm{Cmin}^{-1}$, all four treatments achieved $100 \%$ kill, whereas none of the four treatments achieved $100 \%$ kill when using the heating rate of $18^{\circ} \mathrm{C} \mathrm{min}^{-1}$ (Table 5). The added thermal mortality in the treatment using slow heating rates, however, may be the result of the extended ramp period in which the insects were exposed to the elevated temperature. For example, the ramp time from $22^{\circ} \mathrm{C}$ to reach $52^{\circ} \mathrm{C}$ was $30 \mathrm{~min}$ when heating at $1{ }^{\circ} \mathrm{C} \mathrm{min}{ }^{-1}$ compared to $1.7 \mathrm{~min}$ when heating at $18^{\circ} \mathrm{C} \mathrm{min}^{-1}$.

The accumulated LT during ramp periods $\left(\mathrm{M}_{\text {accum }}\right)$ for the three heating rates from initial $22^{\circ} \mathrm{C}$ to the set temperatures was calculated using Eq. (5). The LT accumulated during the ramp period was about $1.8,0.2$, and $0.1 \mathrm{~min}$ (equivalent to holding time at the end temperature) for the heating rates of $1^{\circ} \mathrm{C} \mathrm{min}^{-1}, 10^{\circ} \mathrm{C} \mathrm{min}^{-1}$, and $18^{\circ} \mathrm{C} \mathrm{min}^{-1}$, respectively. Those values were not affected by the end temperatures. Adding the actual holding time listed in Table 5 to the accumulated LT during the ramp period suggested that the corrected treatment times at each temperature increased with the reduction in the heating rates. The accumulated LT had a significant effect on the short holding time at high temperatures. The incomplete kill of all four treatments at $18^{\circ} \mathrm{C} \mathrm{min}^{-1}$ heating rate might be due to little lethality accumulated during the ramp period at the $18^{\circ} \mathrm{Cmin}^{-1}$. The large difference in the mortality (Table 5) between $10^{\circ} \mathrm{Cmin}^{-1}$ and $18^{\circ} \mathrm{Cmin}^{-1}$ may not have been caused by the small difference in the calculated cumulative LT. Explanation for the discrepancy requires further investigation.

This analysis has shown that treatments in which different heating rates were used to achieve the same holding temperature were not equivalent, and thus did not impart the same heat lethality. With slow heating rates, the insects would have been exposed to the lethal temperatures for a longer time than with treatments using faster rates. The contribution of the ramp period can be very significant at high temperatures if the heating rate is small.

Neven (1998a) observed that at heating rates between $0.13^{\circ} \mathrm{C} \mathrm{min}^{-1}$ and $0.2^{\circ} \mathrm{C} \mathrm{min}^{-1}$, the slower the rate of heating, the longer the codling moth larvae had to be exposed to the final treatment temperature to achieve 95\% mortality. Lester and Greenwood (1997) also reported that a low heating rate and long exposure of insects to elevated but non-lethal temperatures $\left(<42^{\circ} \mathrm{C}\right)$ may condition insects such that subsequent treatment at lethal temperatures above $42^{\circ} \mathrm{C}$ are less effective. This implies that higher heating rate should provide greater mortality (require smaller 
LT) because of a lack of non-lethal temperature conditioning of the insects. In this study, the total accumulated lethality required for $100 \%$ kill of the larvae appeared to be slightly higher at $1^{\circ} \mathrm{C} \mathrm{min}{ }^{-1}$ than at $18^{\circ} \mathrm{C} \mathrm{min}^{-1}$. This is contrary to what was observed by Neven (1998a). It is clear that the heating rates used in this study were much greater than those used by the above author and that the relatively long ramp time at even the lowest heating rate $\left(1^{\circ} \mathrm{C} \mathrm{min}{ }^{-1}\right)$ tested in this study might not be adequate to allow insects to develop thermotolerance.

\section{Conclusions}

The heating block system was suitable for determining experimental data concerning temperature and heating rate effects on insect susceptibility to heat. Complete kill of 600 insects was achieved at a heating rate of $18^{\circ} \mathrm{C} \mathrm{min}^{-1}$ with a minimum exposure time of $50,15,5$, and 2 min at $46^{\circ} \mathrm{C}, 48^{\circ} \mathrm{C}, 50^{\circ} \mathrm{C}$, and $52^{\circ} \mathrm{C}$, respectively. The fundamental 0.5 th reaction model was suited for predicting the thermal death kinetics of codling moth larvae. The activation energy for thermal kill of fifth-instar codling moth was about $473 \mathrm{~kJ} \mathrm{~mol}^{-1}$ both from a TDT curve and an Arrhenius plot. The LT accumulated during the ramp period to the end-point temperature was about $1.8,0.2$, and $0.1 \mathrm{~min}$ for the heating rates of $1^{\circ} \mathrm{Cmin}^{-1}, 10^{\circ} \mathrm{Cmin}^{-1}$, and $18^{\circ} \mathrm{C} \mathrm{min}^{-1}$, respectively. The faster heating rate tended to require a longer holding time at the end temperatures to achieve similar mortality of codling moth larvae compared to the slower rate with test heating range. Fifth-instar codling moths were not able to increase their thermal tolerance with a decrease in the heating rate in the tested range. The methods and concepts described in this report may be extended to study other infesting pests of commodities for which heat treatment is being considered as an alternative quarantine treatment.

\section{Acknowledgements}

This research was supported by grants from the USDA NRI, USDA IFAFS, and the IMPACT Center of the Washington State University, Pullman, WA. The assistance of Millie Heidt and Shelly Watkins, USDA-ARS, Wapato, WA, and Mr. Frank Younce, WSU Food Processing Pilot Plant manager are highly appreciated.

\section{References}

Alderton, G., Snell, N., 1970. Chemical states of bacterial spores: heat resistance and its kinetics at intermediate water activity. Applied Microbiology 19, 565-572.

Evans, D.E., 1986. The influence of rate of heating on the mortality of Rhyzopertha dominica (L.) (Coleoptera: Bostrychidae). Journal of Stored Products Research 23, 73-77.

Finney, D.J., 1971. Probit Analysis, 3rd Edition. Cambridge University Press, Cambridge, UK.

Ikediala, J.N., Tang, J., Neven, L.G., Drake, S.R., 1999. Quarantine treatment of cherries using 915 MHz microwaves: temperature mapping, codling moth mortality and fruit quality. Postharvest Biology and Technology 16, 127-137.

Ikediala, J.N., Tang, J., Wig, T., 2000. A heating block system for studying thermal death kinetics of insect pests. Transactions of the American Society of Agricultural Engineers 43, 351-358. 
Ikediala, J.N., Hansen, J., Tang, J., Drake, S.R., Wang, S., 2002. Development of saline-water-immersion technique with RF energy as a postharvest treatment against codling moth in cherries. Postharvest Biology and Technology, in press.

Jang, E.B., 1986. Kinetics of thermal death in eggs and first instars of three species of fruit flies (Diptera: Tephritidae). Journal of Economic Entomology 79, 700-705.

Jang, E.B., 1991. Thermal death kinetics and heat tolerance in early and late third instars of the oriental fruit fly (Diptera: Tephritidae). Journal of Economic Entomology 84, 1298-1303.

King, A.D., Bayne, H.G., Alderton, G., 1979. Nonlogarithmic death rate calculations for Byssochlamys fulva and other microorganisms. Applied Environmental Microbiology 37, 596-600.

Landolt, P.J., Chambers, D.L., Chew, V., 1984. Alternative to the use of probit 9 mortality as a criterion for quarantine treatments of fruit fly (Diptera: Tephritidae)-infested fruit. Journal of Economic Entomology 77, 285-287.

Lester, P.J., Greenwood, D.R., 1997. Pretreatment induced thermotolerance in lightbrown apple moth (Lepidoptera: Tortricidae) and associated induction of heat shock protein synthesis. Journal of Economic Entomology 90, 199-204.

Lund, D.B., 1977. Design of thermal processes for maximizing nutrient retention. Food Technology 31, 71-78.

Moats, W.A., 1971. Kinetics of thermal death of bacteria. Journal of Bacteriology 105, 165-171.

Moss, J.I., Chan, H.T., 1993. Thermal death kinetics of Caribbean fruit fly (Diptera: Tephritidae) embryos. Journal of Economic Entomology 86, 1162-1166.

Nelson, S.O., Payne, J.A., 1982. RF dielectric heating for pecan weevil control. Transactions of the American Society of Agricultural Engineers 31, 456-458.

Neven, L.G., 1994. Combined heat treatments and cold storage effects on mortality of fifth-instar codling moth (Lepidoptera: Tortricidae). Journal of Economic Entomology 87, 1262-1265.

Neven, L.G., 1998a. Effects of heating rate on the mortality of fifth-instar codling moth (Lepidoptera: Tortricidae). Journal of Economic Entomology 91, 297-301.

Neven, L.G., 1998b. Respiratory response of fifth-instar codling moth (Lepidoptera: Tortricidae) to rapidly changing temperatures. Journal of Economic Entomology 91, 302-308.

Neven, L.G., Mitcham, E.J., 1996. CATTS (Controlled Atmosphere/Temperature Treatment System): a novel tool for the development of quarantine treatments. Journal of American Entomology 42, 56-59.

Neven, L.G., Rehfield, L.M., 1995. Comparison of pre-storage heat treatments on fifth-instar codling moth (Lepidoptera: Tortricidae) mortality. Journal of Economic Entomology 88, 1371-1375.

Rao, M.A., Lund, D.B., 1986. Kinetics of thermal softening of foods - a review. Journal of Food Process Preservation $10,311-329$.

Sokhansanj, S., Wood, H.C., Venkatesan, V.S., 1990. Simulation of thermal disinfestation of hay in rotary drum dryers. Transactions of the American Society of Agricultural Engineers 33, 1647-1651.

Stumbo, C.R., 1973. Thermobacteriology in Food Processing. Academic Press Inc., New York.

Tang, J., Sokhansanj, S., 1993. Drying parameter effects on lentil seed viability. Transactions of the American Society of Agricultural Engineers 36, 855-861.

Tang, J., Ikediala, J.N., Wang, S., Hansen, J.D., Cavalieri, R.P., 2000. High-temperature-short-time thermal quarantine methods. Postharvest Biology and Technology 21, 129-145.

Thomas, D.B., Mangan, R.L., 1997. Modeling thermal death in the Mexican fruit fly (Diptera: Tephritidae). Journal of Economic Entomology 90, 527-534.

Toba, H.H., Howell, J.F., 1991. An improved system for mass-rearing codling moths. Journal of the Entomological Society of British Columbia 88, 22-27.

UNEP, 1995. Montreal Protocol on substances that deplete the ozone layer. Report of methyl bromide technical options committee: 1994 assessment. United Nations Environmental Program, Ozone Secretariat, Nairobi, Kenya.

Waddell, B.C., Jones, V.M., Petry, R.J., Sales, F., Paulaud, D., Maindonald, J.H., Laidlaw, W.G., 2000. Thermal conditioning in Bactrocera tryoni eggs (Diptera: Tephritidae) following hot-water immersion. Postharvest Biology Technology 21, 113-128.

Wang, S., Ikediala, J.N., Tang, J., Hansen, J.D., Mitcham, E., Mao, R., Swanson, B., 2001a. Radio frequency treatments to control codling moth in in-shell walnuts. Postharvest Biology and Technology 22, 29-38. 
Wang, S., Tang, J., Cavalieri, R., 2001b. Modeling fruit internal heating rates for hot air and hot water treatments. Postharvest Biology and Technology 22, 257-270.

Wang, S., Tang, J., Johnson, J.A., Hansen, J.D., 2002. Thermal death kinetics of fifth-instar Amyelois transitella (Walker) (Lepidoptera: Pyralidae). Journal of Stored Products Research, in press.

Yokoyama, V.Y., Miller, G.T., Dowell, R.V., 1991. Response of codling moth (Lepidoptera: Tortricidae) to high temperature, a potential quarantine treatment for exported commodities. Journal of Economic Entomology 84, $528-531$. 